\title{
GEORGE HUGH RECKNELL
}

Hugh Reck NELL died at his home in Steyning on 7 July 1975, in his 82nd year. He had been in frall health for sonie time but up to the end he retained his perceptive mind and his sense of humour. Only the day before he died he had visited the home of an old friend of his National Mutual days and had been in noticeably good form.

Hugh Recknell was born in London in 1893 and was educated at Christ's Hospital. On leaving school he joined the Caledonian in Edinburgh and commenced his studies for the Faculty examinations, which he completed in 1915. The Faculty pass list for that year shows four successful candidates for the Fellowship in order of merit. Hugh was third and immediately above him was Andrew Davidson, later General Manager of the Standard, who was to become Hugh's life-long friend.

War service followed. A lieutenant in the Cameronians, Hugh saw active service in France in 1916 and subsequently in Palestine and Syria. Demobilized in 1919, he joined the Friends Provident in London and set about achieving the double. He qualified as a Fellow of the Institute in 1923. During this time he also studied economics at the London School of Economics.

Soon after qualification he was the successful candidate among fifteen others for the position of Assistant Actuary at the National Mutual, being interviewed for the post by Geoffrey Marks and, later, by the Chairman, Maynard Keynes. Those hours at the LSE may have helped, for Hugh was able to say to Keynes that he had heard him lecture there! Both Gcoffrcy Marks and Maynard Keynes were to be a strong influence on the young man, then still under 30 , not only in his professional life but culturally as well. He succeeded Geoffrey Marks as Chief Officer of the National Mutual in 1932, a position he held until his retirement in 1956.

During his professional life Hugh Recknell was continuously active in the affairs of the Institute. He served on the Council for no less than 22 years, was Honorary Secretary from 1939 to 1941, Vice-President from 1941 to 1945 and Treasurer from 1950 to 1952 . When this last appointment was announced it did look to those around him that the office of President would follow in due course; so it must have done to Hugh, and it is no secret now that not being elected to that office was one of the disappointments of his life, though he gave no sign of this at the time. Service to the actuarial profession was not only through the Institute, however. He was a member of the Council of the Faculty from 1944 to 1948 and it gave him especial pleasure when, though based south of the border, he was appointed a Vice-President in 1950.

There is no need to say much about Hugh Recknell's written contributions on actuarial topics, important though they were. One paper to the Institute was required reading for many years; another, 'Insurance against Inflation', submitted to the Faculty in 1949 when his old friend Andrew Davidson was President, was almost prophetic in its discussion of index-linked policies and special distributions of bonuses from capital appreciation.

So far, the account is largely factual. As for the man himself, he had a dignified bearing and authoritative voice which made his presence a commanding one. A tendency to overdo this may not have been popular among his fellows at times and perhaps he realized this himself, for sometimes outside the office he would unbend almost too much, to the concern of those whose duty it was to shepherd him along. An elegance of dress was coupled with a tendency to flamboyance on occasions which was probably acquired from Geoffrey Marks.

Hugh Recknell was widely read and possessed a fine library. He was a master of the English language both spoken and written. The 'mot juste' never secmed to escape him; both on the platform at the Institute and in private conversation the felicity of expression was a delight to listen to. Reflecting the man, his handwriting was bold. He seldom used a fountain pen and would have scorned a ball-point pen if one had ever appeared on his desk. He used an ordinary pen and it was someone's job to see that there was a new nib inserted each day.

This is the picture of an autocrat in the office, which he was. But for all that he was respected by all and admired by most. Underneath there was a very warm-hearted man, ready to help anyone in trouble, understanding of human failings and foibles. He was particularly at ease with 
young people and enjoyed nothing more than a drink with young members after a Students' Society meeting which he may have chaired.

Culturally, Hugh Recknell had an abiding interest in the arts. He must have visited almost every art gallery of note in Europe, including Leningrad and Moscow. He had a love of antique furniture and possessed some fine pieces. He was always up to date with the West End theatre and enjoyed the cinema also, with a curious enthusiasm for cowboy films.

In his later years Hugh Recknell mellowed. Or so it seemed. It would be more correct however to say that the other side of him that always existed now became predominant. One could not but have a strong warmth of feeling for the old man. He made us welcome always at Chantry Green House - that 17th-century house that was his home for 30 years and his pride and joy.

Hugh's first wife, Eileen, died in 1961. He married Jean Addison, Matron of Guy's Hospital, in $\mathbf{1 9 6 2}$ and she survives him. So much is owed to Jean for her devoted attention to Hugh in his later years. Not the easiest of patients was he, as one might imagine.

So passes an actuary of the old school, one of the last of the era. Those of us who knew him well count ourselves fortunate in so many ways.

D. S. ROSE 